На данном этапе развития требования к молодому поколению, возрастают со всех сторон, сейчас создаются все условия для интеграции молодежи в государственную, общественную и социальную сферу. Это процесс на территории Саратовской области осуществляется с помощью эффективной реализацией государственной молодежной политики, поэтому актуальность проведения исследований в данной категории ни вызывает сомнений. А так же доказывает необходимость изучения различных изменений и трансформаций, которые происходят в данной социально-демографической группе. В современных условиях непрерывной модернизации назрела необходимость выявления и научного применения потенциала молодежи как интеллектуального, так и творческого, как одного из важнейших факторов развития всех общественных структур, а также возможности своевременной переориентации молодежной политики на территории области. Проявление патриотизма и желание проявлять свою социальную активность в обществе актуализируют постоянную потребность в качественном исследовании и необходимости улучшения положения молодежи, в уменьшении и локализации рискогенных факторов в молодежной среде, в поддержке инициатив молодежи и проведение огромного количества форумов и оказание грантовой поддержки для реализации своих инициатив, данными вопросами постоянно занимаются все органы власти на территории Саратовской области, что говорит о эффективности реализации молодежной политики.

$$
* * *
$$

1. Ожегов С.И., Швдеова Н.Ю. Толковый словарь русского языка.22-е изд.-М.: Русский язык, 1990.С. 1822

2. См.: Волков Ю.Г.,Бинеева Н.К. Социологическое измерение гражданственности и патриотизма в российских исследованиях // Формирование гражданского патриотизма на Юге России :материалы Школы молодого социолога «Формирование гражданского патриотизма на Юге России» (1-3 ноября 2017 г., Институт социологии и регионоведения ЮФУ, г. Ростов-на-Дону) / отв. ред. Ю.Г. Волков; сост.: Н.З. Губнелова, В.О. Вагина. Ростов н/Д.: Фонд науки и образования, 2017. С. 1017.

3. См.: Пронина Е.И. Особенности воспитания гражданственности и патриотизма старших школьников // Социс. 2011. № 5. С.97-103.

4. См.: Салганова Е.И. Патриотизм учащейся молодежи: состояние, проблемы и формирование. URL: http://elar.urfu.ru/bitstream/10995/59134/1/978-5-91256-403-1_2018_063.pdf (дата обращения: 15.03.2020).

5. См.: Воробьева Н.В., Яблочко Е. Патриотизм современного студента // Науч.-метод. эл. журнал «Концепт». 2016. Т. 11. С. 531-535.URL: http://e-koncept.ru/2016/86117.htm.

6. Кудринская, Л.А. Добровольческий труд: опыт теоретической реконструкции [Текст] : дис. ... д-ра социолог. наук / Л.А. Кудринская. - М., 2006. - 298 с.

7. Ядов В.А. Саморегуляция и прогнозирование социального поведения личности. Л.: Наука, 2007. С.

\title{
Сайганова Е.В., Тимофеева А.В. \\ Организация дистанционных форм летнего оздоровительного отдыха детей в 2020 году на территории г. Саратова
}

ФГБОУ ВПО «Саратовский государственный университет им. Н.Г.

Чернылиевского»

(Россия, Саратов)

doi: 10.18411/lj-08-2021-106

\section{Аннотация}

Статья посвящена анализу организации летнего оздоровительного отдыха детей на территории г. Саратова в каникулярное время в условиях пандемии.

Ключевые слова: дети, отдых, пандемия, профилактическая деятельность. 


\section{Abstract}

The article is devoted to the analysis of the organization of summer recreation for children in the territory of Saratov during the vacation time in the conditions of the pandemic.

Keywords: children, recreation, pandemic, preventive activities.

Новое время диктует новые формы организации работы с детьми в период летних каникул. Актуальной стала организация досуга детей в дистанционном формате.

Руководствуясь письмом Министерства просвещения России от 7 мая 2020 года № ВБ-976/04 «О реализации курсов внеурочной деятельности, программ воспитания и социализации, дополнительных общеразвивающих программ с использованием дистанционных образовательных технологий» образовательные учреждения города Саратова разработали планы работы по организации досуга детей и подростков на летний период в дистанционном формате. Информация о проводимых мероприятиях, реализации дополнительных краткосрочных общеразвивающих программ размещается на официальных сайтах учреждений и в социальных сетях.

Организация занятости обучающихся в летний период 2020 года включает не только социальную защиту, работу по профилактике преступлений и правонарушений обучающихся, но и способствует творческому развитию, обогащению духовного мира и интеллекта детей и подростков, их социализации с учетом реалий современной жизни через организованные формы.

Для успешной реализации летнего отдыха детей происходит системное информирование родителей (законных представителей) о планируемых мероприятиях, индивидуальная работа с родителями обучающихся «группы риска».

В июне, июле 2020 года для детей и подростков проведено более 470 мероприятий в дистанционном формате, в которых приняло участие около 65 тысяч человек.

Для участия в федеральном проекте «Большая перемена» прошли регистрацию 1048 учащихся из 67 общеобразовательных учреждений.

В федеральном проекте «Билет в будущее» приняли участие 8365 учащихся из 101 общеобразовательного учреждения.

Также школьники приняли активное участие в федеральном проекте «Проектория», в онлайн-конкурсах платформы «Учи.ру», в работе онлайн кружков «Кружковое движение», «Яндекс Школа», Международном конкурсе детскоюношеского творчества «С днём рождения, Светофор!», Всероссийском гражданскопатриотическом проекте «Дети-герои», Всероссийском конкурсе «Наша Победа 75», Всероссийской акции «Мое детство - война», Всероссийском проекте «Экозабота», Всероссийском экологическом проекте «Мои зеленые сказки», Всероссийских акциях «\#ОкнаРоссии»; «\#МыРоссия», Всероссийском онлайн-челлендже \#РусскиеРифмы, Международном конкурсе детского театрального творчества «Петрушка», Международной выставке-акции «Спасибо врачам» и других.

Обучающиеся и их родители участвовали в онлайн - и офлайн-акциях: «Бессмертный полк - онлайн», «Памяти Героев», «Окна Победы», «Свеча памяти», «Минута молчания», «Парад Победы», «Наследники Победы», флешмобах «Флаги России», «\#РоссияВобъективе», «\#ЯлюблюРоссию», флешмобе в Tik Tok «Pocсия в каждом доме», сетевой акции «Ромашка - символ семьи», флешмобе «Голубь мира», акции «Я рисую мелом», акции «Свеча памяти», мероприятии «Шококвест», дистанционных уроках по правилам дорожного движения, онлайн-выставке рисунков «Моя Россия» и других дистанционных мероприятиях.

Большое внимание образовательными учреждениями уделялось профилактической деятельности в летний период через конкурсы рисунков, роликов, сочинений и другие формы работы: классные часы в режиме онлайн в рамках месячника антинаркотической направленности, классные часы в режиме онлайн 
«Безопасное лето» в рамках единого Дня безопасности, мероприятия «Азбука безопасности», «Безопасные каникулы», «Здоровое лето 2020», «Дети летать не умеют», «Один дома» - памятка для детей и родителей по правилам личной безопасности, «Правила дорожной безопасности», «Я несу ответственность за свои поступки», викторина по предупреждению правонарушений и преступлений несовершеннолетних, заочный детский конкурс социальной рекламы «У воды без беды!» по правилам безопасного поведения в летний период, online-конференция по профилактике наркомании «Наркотикам - HET!», просветительскую акцию «Молодежь за здоровый образ жизни». Организация участия ребят в посещении виртуальных выставок, онлайн повторении школьной программы, занятиях в виртуальной библиотеке, в квестах и викторинах, проекте государственного музея К.А. Федина «Лето в городе», акции «Лето - это маленькая жизнь», викторины «Кто здесь адмирал?» Исторического парка «Россия - моя история».

При реализации спортивно-оздоровительного направления воспитательной работы запланированы и проводятся «Утренняя зарядка», физкультура дома, дистанционные посещения спортивных музеев страны и мира, учебно-тренировочные занятия по индивидуальным планам.

Работа муниципальных учреждений дополнительного образования проходит летом под девизом: \#ТворимВместеДома.

Педагоги дополнительного образования организуют работу, исходя из технических возможностей учащихся: с использованием мобильных мессенджеров, социальных сетей, видео или телефонной связи, официальных сайтов учреждений.

Активно вовлекаются несовершеннолетние в различные мероприятия: онлайн конкурсы фотографий «Семейные ценности», «От улыбки всем смешней» «Самый лучший день», «Дружная семейка», посещение онлайн - зоопарка, Арт-марафон «Мир увлечений детей», челлендж «Танцуем вместе», онлайн-клип «Все поют «Солнечный круг», онлайн-перфоманс «Должны смеяться дети», фото-выставку «Я и мой культурный дневничок», челлендж в социальной сети Инстаграм «Мое лето».

Интересно и увлекательно прошли мероприятия, посвящённые Дню семьи, любви и верности. Были организованы разнообразные конкурсы, челленджи, в которых приняли участие педагоги, дети и родители: онлайн-крафтинг «Букет из ромашек», онлайн арт-класс «Ромашковое счастье», селфи-марафон «Я и семья», онлайн-рассказ «История любви и верности».

Положительные результаты, отзывы детей и родителей получил дистанционный лагерь КИВИ, организованный в июне месяце Дворцом творчества детей и молодежи имени О.П. Табакова. Само название «КИВИ» расшифровывается как Кладовая Интересных и Веселых Идей. Педагоги Дворца подготовили для ребят в возрасте от 5 до 10 лет разнообразный спектр занятий: мастер-классы, танцевальные разминки, театральные пробы, познавательные викторины, занятия по вокалу, робототехнике, рисованию, лепке, моделированию из бумаги.

С отрядами, которым дети придумали названия и девизы, вожатыми лагеря проводились игры на знакомство, сплочение, творческое развитие. В конце каждого дня дети и взрослые вместе анализировали дела и события. Всего в работе лагере приняла участие 51 семья.

Каждый день лагеря «КИВИ» был посвящен отдельной тематике. Например, день спорта, день правил дорожного движения, день сказок, музыки, красок. Ко Дню России была проведена интерактивная викторина «Саратов с высоты птичьего полета».

Центр технического творчества детей и молодежи запустил Арт-челендж «Детские мечты», участники челленджа записали видео, на котором ответили на вопрос «Что такое детство?» и нарисовали общий рисунок. В мероприятии приняло участие 53 учащихся.

В Центре детского творчества Кировского района для пользователей сети instagramm, dnevnik.ru, ВКонтакте на страницах образовательных учреждений была 
проведена виртуальная прогулка по родному городу «Такой знакомый и не знакомый Саратов».

Руководитель театра уличных миниатюр «Гуливер» организовал на уoutube канале для детей и родителей ТеатрДома, в рамках которого состоялось знакомство участников с произведениями великих отечественных писателей и поэтов в формате флешмоба \#Пушкиннашевсе и «Читаем Дома А.С. Пушкин».

В честь празднования Дня России коллективами образовательных учреждений был подготовлен комплекс онлайн мероприятий. Запущен песенный флешмоб \#ЗасемьюЗаРодинуЗаРоссию, в котором приняли участие все желающие. В исполнении детей и родителей прозвучали замечательные песни о любви к Родине, о красоте родных просторов. В рамках онлайн-экскурсии «Неизвестная Россия» учащиеся и родители (законные представители) посетили пять крупных городов России с уникальной историей, познакомились с неизвестными фактами о каждом городе, а видео-лекция «Уголки России» рассказала о величии природы нашей Родины.

С участием студии современного танца «Фишка» и «Флеш» организовали онлайн-флешмоб «Давай, Россия!». Ярким, насыщенным и интересным получился праздничный онлайн-перфоманс «Мы дети твои, Россия!», в котором приняли участие детские творческие коллективы Центра детского творчества Кировского района.

Помимо учебной деятельности педагоги оказывают помощь родителям в организации культурного досуга детей: размещают ссылки на он-лайн экскурсии, видео концертов, спектаклей, кино и мультфильмов, подборки интересных развлекательных и познавательных ресурсов.

В летний период дети и их родители принимали активное участие в городских массовых мероприятиях-конкурсах: детского технического творчества «RUKAMI», декоративно-прикладного творчества «Арт-проект «Мастерилка», видеороликов «Семейные традиции», фотографий «Самый лучший день».

Также в период летних каникул реализовывалось более 50 дополнительных общеразвивающих и краткосрочных программ по различным направленностям, дистанционно работали творческие объединения и спортивные секции, в которых занималось более 5 тысяч детей.

Классные руководители, руководители творческих объединений и спортивных секций поддерживают постоянную связь с детьми и родителями, предлагая различные формы организации досуга детей в летний период, особенно учащимся, состоящим на различных видах учета.

$$
* * *
$$

1. Абрам Н. Словарь русских синонимов и сходных по смыслу выражений / Н. Абрамо. -8-е изд., стер. - М.: Русские словари [и др.], 2008. -667 с.

2. Ожегов С.И. Толковый словарь русского языка: около 100000 слов, терминов и фразеологических выражений / С.И. Ожегов; под ред. Л.И. Скворцова. - 26-е изд., испр. и доп. - М.: Оникс [и др.], 2009. $-1359 \mathrm{c}$.

\section{Сайганова Е.В., Тимофеева А.В. \\ Сетевое взаимодействие в работе учреждений дополнительного образования г. Саратова}

ФГБОУ ВПО «Саратовский государственный университет им. Н.Г. Чернышевского»

doi: $10.18411 / \mathrm{lj}-08-2021-107$

(Россия, Саратов)

\section{Аннотация}

Статья посвящена анализу сетевого взаимодействия в работе муниципальных учреждений дополнительного образования г. Саратова, о проводимых ими мероприятиях в условиях пандемии. 